\title{
Baicalin inhibits breast cancer development via inhibiting IKB kinase activation in vitro and in vivo
}

\author{
YANG GAO $^{1 *}$, HUI LIU ${ }^{1 *}$, HONGZHI WANG ${ }^{2 *}$, HAILONG HU $^{1}$, HONGJUAN HE $^{1}$, NING GU ${ }^{1}$, XIAO HAN $^{1}$, \\ QIAN GUO $^{1}$, DONG LIU ${ }^{1}$, SHUANG CUI ${ }^{1}$, HONGJIANG SHAO ${ }^{3}$, CHENGJUN JIN ${ }^{4}$ and QIONG WU ${ }^{1}$ \\ ${ }^{1}$ School of Life Science and Technology, Harbin Institute of Technology, Harbin, Heilongjiang 150001; \\ ${ }^{2}$ Department of Laboratory Diagnosis, The Fifth Affiliated Hospital of Harbin Medical University, Daqing, \\ Heilongjiang 163000; ${ }^{3}$ Department of Forensic Medicine, Harbin Medical University, Harbin, Heilongjiang 150081; \\ ${ }^{4}$ The First Affiliated Hospital of Harbin Medical University, Harbin, Heilongjiang 150001, P.R. China
}

Received May 17, 2018; Accepted September 12, 2018

DOI: 10.3892/ijo.2018.4594

\begin{abstract}
The aim of the present study was to investigate the effect and therapeutic potential of baicalin in breast cancer. Baicalin is used to treat inflammatory diseases. The effects of baicalin were assessed in breast cancer MCF-7 and MDA-MB-231 cells, and human breast cancer xenograft mice. Cells were treated with 0,20 or $30 \mu \mathrm{M}$ baicalin for $48 \mathrm{~h}$, while xenograft mice were treated with intraperitoneal injection of 0,100 or $200 \mathrm{mg} / \mathrm{kg}$ baicalin for 30 days. The results demonstrated that treatment with baicalin dose-dependently suppressed breast cancer cell invasion, migration and proliferation, and also induced G1/S-phase cell cycle arrest in vitro and in vivo. Baicalin alleviated inflammation injury and inhibited the secretion of tumor necrosis factor (TNF)- $\alpha$ and interleukin (IL)-1 $\beta$, thus suppressing nuclear factor (NF)-kB-p65 activation via inhibition of IкB kinase. Investigation of the mechanism underlying baicalin activity indicated that it inhibited protein expression of NF-kB-p65, leading to NF-KB-induced increased expression of CCND1, BCL2, $\mathrm{BIRC} 2$ and $\mathrm{BIRC} 3$, thus inhibiting cell proliferation, invasion and migration and suppressing anti-apoptotic factors in vitro and in vivo. In addition, baicalin did not affect non-tumorigenic normal breast epithelial cells. These results indicate that baicalin may exert therapeutic effects in breast cancer.
\end{abstract}

\section{Introduction}

Breast cancer is the most common type of malignancy worldwide and the second leading cause of cancer-related mortality

Correspondence to: Dr Qiong Wu, School of Life Science and Technology, Harbin Institute of Technology, 92 West Da-zhi Street, Harbin, Heilongjiang 150001, P.R. China

E-mail: kigo@hit.edu.cn

${ }^{*}$ Contributed equally

Key words: baicalin, breast cancer, inflammation, ІкВ kinase, tumor suppressor in women $(1,2)$. Recent advances in breast cancer detection and treatment have decreased the mortality rate attributable to breast cancer. However, the side effects of radiotherapy and chemotherapy, such as immunosuppression, recurrence and metastasis, remain challenging and adversely affect the quality of life of breast cancer patients $(3,4)$. A number of traditional Chinese herbal medicines have been suggested as potential therapeutic options, due to their relative lack of side effects.

Constitutive activation of the transcription factor nuclear factor $(\mathrm{NF})-\kappa \mathrm{B}$ stimulates proliferation and metastasis and inhibits apoptosis of breast cancer cells. NF- $\kappa \mathrm{B}$ activitystimulating signals have been shown to cause dissociation of $\mathrm{I} \kappa \mathrm{B}$, allowing $\mathrm{NF}-\kappa \mathrm{B}$ dimers to translocate to the nucleus and alter gene expression, in order to activate anti-apoptotic genes and promote the transcription of genes associated with cancer growth, invasion and metastasis. This makes $\mathrm{NF}-\kappa \mathrm{B}$ a key factor in enabling precancerous and malignant cells to escape apoptosis (5-7). Inhibition of $N F-\kappa B$ activity results in the partial release of cells from the $\mathrm{G} 2 / \mathrm{M}$ arrest following curcumin treatment of human breast cancer MCF-7 cells $(8,9)$. Therefore, $\mathrm{NF}-\kappa \mathrm{B}$ may represent an effective target for controlling tumor invasion and metastasis.

Baicalin is one of the predominant flavonoids isolated from the dry root of Scutellaria baicalensis Georgi (Huang-Qin, a medicinal plant), an important traditional Chinese medicinal herb used to treat diseases of the central nervous system (CNS), hepatic disorders and inflammatory conditions, among others $(10,11)$. Furthermore, baicalin has multiple biological functions, including anti-inflammatory, antioxidant, antiapoptotic and immune regulation properties $(12,13)$. Baicalin reduces the acute hepatic injury induced by $\mathrm{CCl}_{4}$ and promotes early recovery of liver function (14). Baicalin inhibits HepG2 hepatoblastoma cells through oxidative/nitrative stress (15). Evidence suggests that the potential antioxidant and antiinflammatory properties of this compound are largely due to its ability to enhance an antioxidant status and to suppress the expression of several inflammatory cytokines by attenuating the activity of $\mathrm{NF}-\kappa \mathrm{B}(12,16)$. Dinda et al reported that baicalin inhibited reactive oxygen species (ROS) production in arteriosclerotic vascular disease by suppressing the activation of the NF- $\mathrm{BB}$ signaling pathway (17). Wang et al reported that 
baicalin exerts an inhibitory effect on inflammation-related collagen-induced arthritis via inhibition of the activation of the NF- $\mathrm{B}$ signaling pathway (18). Given its ability to inhibit the activation of $\mathrm{NF}-\kappa \mathrm{B}$ signaling, it was hypothesized that baicalin may suppress breast cancer growth. To the best of our knowledge, no previous studies have investigated this possible effect of baicalin.

In the present study, the breast cancer cell lines MCF-7 and MDA-MB-231 and a xenograft mouse model were treated with baicalin, with the aim of determining the therapeutic potential of this compound in breast cancer and elucidating the role of $\mathrm{NF}-\kappa \mathrm{B}$ in the effects of baicalin.

\section{Materials and methods}

Cell treatment. The breast cancer cell lines MCF-7, MDA-MB-231 and MCF-10 were purchased from Cell Applications, Inc. (San Diego, CA, USA). The cells were cultured in cell growth medium supplemented with $100 \mathrm{IU} / \mathrm{ml}$ penicillin and $100 \mu \mathrm{g} / \mathrm{ml}$ streptomycin at $37^{\circ} \mathrm{C}$ in a humidified incubator with $5 \%$ carbon dioxide $\left(\mathrm{CO}_{2}\right)$ and $95 \%$ air.

The cell growth medium was replaced with serum-free medium for an additional 24-h culture prior to further treatments. Cells were suspended at a density of $2 \times 10^{6}$ cells $/ \mathrm{ml}$ for experiments. In the mechanism experiments, cells treated with serum-free medium alone served as the control group. The cells were treated with 20 or $30 \mu \mathrm{M}$ baicalin in Dulbecco's modified Eagle's medium for $48 \mathrm{~h}$. The concentrations of baicalin were selected as previously described $(10-13,18)$.

In vivo tumorigenicity and baicalin treatment. The present study was approved by the Ethics Committee for Animal Experimentation of the School of Life Science and Technology, Harbin Institute of Technology. All animal experiments were performed according to the Guidelines for the care and use of experimental animals approved by the Heilongjiang Province People's Congress (http://www.nicpbp.org.cn/sydw/ CL0249/2730.html). Female BALB/c nude mice, 5 weeks old and weighing $\sim 15 \mathrm{~g}$, were purchased from the Harbin Veterinary Research Institute (Harbin, China). The animals were housed in a clean and ventilated environment under standard laboratory conditions (temperature $22 \pm 1^{\circ} \mathrm{C}$, relative humidity $50-70 \%$, and a 12 -h light/dark cycle). Standard food and water were provided ad libitum throughout the experiments. The animals were allowed to acclimatize to their surroundings over 7 days to eliminate the effect of stress prior to the initiation of the experiments, and then randomly divided into three groups (control, 100 and $200 \mathrm{mg} / \mathrm{kg}$ groups; $\mathrm{n}=6$ per group) for the following tumorigenicity and baicalin treatment experiments.

MDA-MB-231 cells (1x105/injection) were suspended in $100 \mu \mathrm{l}$ phosphate-buffered saline (PBS) containing $50 \%$ Matrigel (BD Biosciences, Franklin Lakes, NJ, USA) and injected into the mammary fat pad of 4-5-week-old female nude mice. One week later, the control mice received PBS (1 ml/kg, once daily i.p.), while 100 and $200 \mathrm{mg} / \mathrm{kg}$ group mice received daily i.p. injections of baicalin (>95\% purity; Sigma-Aldrich; Merck KGaA, St. Louis, MO, USA) at doses of 100 and $200 \mathrm{mg} / \mathrm{kg}$, respectively. The concentrations of baicalin were selected as previously described $(10-13,18)$.
Tumor size was measured every 5 days for 4 weeks, starting 5 days after tumor cell implantation. The tumor volume was calculated according to the following formula: $\mathrm{V}=\mathrm{L} \times \mathrm{W}^{2} / 2$, where V, volume $\left(\mathrm{mm}^{3}\right)$; L, length $(\mathrm{mm})$; and $\mathrm{W}$, width $(\mathrm{mm})$.

Cell viability. Cells were cultured using the abovementioned method, diluted to $2 \times 10^{6}$ cells $/ \mathrm{ml}$, seeded into 96 -well plates (100 $\mu \mathrm{l} /$ well) and incubated for $24 \mathrm{~h}$, followed by the addition of 20 or $30 \mu \mathrm{M}$ baicalin and further incubation for $72 \mathrm{~h}$. According to the manufacturer's recommendations, $20 \mu 1$ 3-(4,5-dimethylthiazol-2-yl)-2,5-diphenyl-2H-tetrazoliumbromide solution ( $5 \mathrm{mg} / \mathrm{ml}$ in PBS; Sigma-Aldrich; Merck KGaA) was added to each well and incubated with cells under standard conditions for $4 \mathrm{~h}$. Subsequently, the formazan crystals in each well were dissolved in dimethyl sulfoxide, after removal of the medium. Finally, the optical density at $490 \mathrm{~nm}$ was measured using an enzyme-linked immunosorbent microplate reader (Bio-Rad Laboratories, Inc., Hercules, CA, USA). The results are expressed as the mean of triplicate experiments.

Cell cycle analysis. Untreated cells and those treated with baicalin were dissociated and washed with PBS for cell cycle analysis. The cells were incubated in PBS containing $500 \mathrm{U} / \mathrm{ml}$ RNase (Sigma-Aldrich; Merck KGaA) at $37^{\circ} \mathrm{C}$ for $15 \mathrm{~min}$, incubated with $50 \mu \mathrm{g} / \mathrm{ml}$ propidium iodide (PI) at $4^{\circ} \mathrm{C}$ in the dark for $2 \mathrm{~h}$, and analyzed to determine the percentage of 10,000 cells in each of three cell cycle compartments (G0/G1, $\mathrm{S}$ and $\mathrm{G} 2 / \mathrm{M}$ ) using a fluorescence-activated cell analyzer (Becton-Dickinson, Mountain View, CA, USA). Modifit LT 2.0 software was used to perform data analysis, and CELLQuest software (both from Becton-Dickinson) was used to quantify the percentage of cells in each compartment.

Transwell assay. To measure cell invasion, $8-\mu \mathrm{m}$ pore $24-w e l l$ Matrigel invasion chambers (Corning Inc., Corning, NY, USA) were used according to the manufacturer's instructions. A total of $2 \times 10^{4}$ cells were seeded into each well. DMEM with $0.1 \%$ FBS was added to the upper chamber, while DMEM supplemented with $10 \%$ FBS was added to the lower chamber well to promote cell invasion. After $24 \mathrm{~h}$ of incubation at $37^{\circ} \mathrm{C}$ with $5 \% \mathrm{CO}_{2}$, non-invading cells were removed from the top well, while migrated cells were quantified by capturing photographs of 6 independent visual fields under an Olympus BX51 microscope (Olympus Co., Tokyo, Japan), and was stained with $0.1 \%$ crystal violet solution. Independent experiments were repeated at least three times.

Scratch wound healing assay. A scratch wound healing assay was performed to evaluate the migration of untreated cells and cells treated with baicalin. In brief, MCF-7 and MDA-MB-231 cells were seeded in 6-well plates and cultured with DMEM supplemented with $10 \%$ FBS. After reaching confluence, each well was scratched with a $200-\mu l$ pipette tip. After 12 and $24 \mathrm{~h}$ of incubation, 6 wound healing areas were imaged and the distance between the two edges was analyzed by ImageJ software, version 1.48 (National Institutes of Health, Bethesda, MD, USA).

Dual-luciferase reporter assay. The pRL-TK and recombinant NF-kB luciferase reporter plasmids (Thermo Fisher Scientific, 
Inc., Waltham, MA, USA) were co-transfected into MCF-7 and MDA-MB-231 cells for measurement of NF-kB reporter activity. Transfected cells were harvested $48 \mathrm{~h}$ after transfection, and luciferase activity was determined by Fluoroskan Ascent FL (Thermo Fisher Scientific, Inc.) configured for dual assays. The relative luciferase activity was normalized to Renilla luciferase activity. All experiments were performed in triplicate wells.

Enzyme-linked immunosorbent assay (ELISA) measurement of TNF- $\alpha$ and IL-1 $\beta$ levels in mouse serum and cell culture supernatants. At day 30 of baicalin treatment, the mice were anesthetized with intraperitoneal injection of $10 \%$ chloral hydrate (400 $\mathrm{mg} / \mathrm{kg}$ body weight). Blood samples were collected from the abdominal aorta using syringes, and centrifuged for $30 \mathrm{~min}\left(3,000 \mathrm{xg}\right.$ at $\left.4^{\circ} \mathrm{C}\right)$. Serum samples were stored at $-80^{\circ} \mathrm{C}$ until use. The mice were then euthanized by cervical dislocation. To determine cytokine levels in vitro, MCF-7 and MDA-MB-231 cells were treated with or without baicalin using the method described above. The supernatants of culture plates were harvested from each well. TNF- $\alpha$ and IL-1 $\beta$ levels in the serum and culture supernatants were measured using mouse TNF- $\alpha$ and IL- $1 \beta$ ELISA kits (R\&D Systems, Minneapolis, MN, USA), according to the manufacturer's instructions.

Western blotting. MCF-7 and MDA-MB-231 cells and 0.3-g tumor samples from mice were treated with RIPA lysis buffer supplemented with protease inhibitor cocktail and protein phosphatase inhibitor. The protein concentration was quantified using a DC protein kit (Bio-Rad Laboratories). Samples were then separated, transferred to PVDF membranes, and incubated with 1:1,000 dilution primary antibodies overnight at $4^{\circ} \mathrm{C}$. The primary antibodies used were anti-phospho-NF-kB-p65 (Ser536) (rabbit mAb, catalog no. 3033), anti-phosphoIKK $\alpha / \beta$ (Ser176/180) (rabbit mAb, catalog no. 2697) and anti-IkB $\alpha$ (rabbit $\mathrm{mAb}$, catalog no. 4812). The anti-total NF-kB-p65 (rabbit mAb, catalog no. 8242), anti-total-IKK $\beta$ (rabbit mAb, catalog no. 2370) and anti- $\beta$-actin antibodies (rabbit mAb, catalog no. 4970) were used as loading controls. On the following day, the membranes were incubated with secondary antibody (anti-rabbit IgG, catalog no. 4414) for $2 \mathrm{~h}$ at room temperature. All antibodies were purchased from Cell Signaling Technology (Danvers, MA, USA). The bands were visualized using an ECL Plus western blotting detection system (GE Healthcare, Milwaukee, WI, USA).

Reverse transcription-polymerase chain reaction (RT-PCR) and quantitative PCR (RT-qPCR). Total RNA was extracted from MCF-7 and MDA-MB-231 cells and xenograft tumor tissues using TRIzol reagent (Invitrogen; Thermo Fisher Scientific, Grand Island, NY, USA) according to the manufacturer's instructions. Equal amounts $(1 \mu \mathrm{g})$ of total RNA were used to perform reverse transcription using PrimeScript ${ }^{\mathrm{TM}}$ RT reagent kit (Takara, Tokyo, Japan). For the determination of the expression of various genes in MCF-7 and MDA-MB-231 cells and xenograft tumor tissues, RT-qPCR was performed using the following primers: $C C N D 1$, forward, 5'-AGAAGCTGTGCATC TACACCGACA-3' and reverse, 5'-TGATCTGTTTGTTCTCCT CCGCCT-3'; BCL2, forward, 5'-TGAGCAGAGTCTTCAGAG ACAGCC-3' and reverse, 5'-ATGTGTGTGGAGAGCGTCA
ACC-3'; BIRC2, forward, 5'-CCCAAAGACTTTTCCCAGGT CCC-3' and reverse, 5'-ACTGAGCTTCCCACCACAGGCA-3'; BIRC3, forward, 5'-GAATACTCCCTGTGATTAATGCTG CCGTGG-3' and reverse, 5'-TCTCTTGCTTGTAAAGACGTC TGTGTCTTC-3'. The $A C T B$ ( $\beta$-actin) control primers were 5'-CGTTGCTATCCAGGCTGTGCTA-3' and 5'-CCAGGT CCAGACGCAGGATGGC-3'. Quantification of gene expression was determined by comparative quantity, using $A C T B$ gene expression as internal control. The PCR conditions were denaturation at $94^{\circ} \mathrm{C}$ for $45 \mathrm{sec}$, annealing at $57^{\circ} \mathrm{C}$ for $30 \mathrm{sec}$, and extension at $72^{\circ} \mathrm{C}$ for $1 \mathrm{~min}$, for 40 cycles.

Statistical analysis. Data are expressed as mean \pm standard error of the mean and were analyzed using GraphPad Prism version 5.0 (GraphPad Software, La Jolla, CA, USA). All calculated significant differences were based on one-way analysis of variance and the post hoc Tukey's test. For direct comparisons between two groups, the Student's t-test was used. $\mathrm{P}<0.05$ was considered to indicate statistically significant differences.

\section{Results}

Baicalin suppresses proliferation and induces G1/S arrest in breast cancer cells. To evaluate the effect of baicalin on breast cancer, cell proliferation was assessed. The cells were manually counted in 6 wells per group. The results demonstrated that baicalin reduced cell proliferation from 48 to $72 \mathrm{~h}$ in MCF-7 and MDA-MB-231 cells, indicating that this compound can inhibit breast cancer cell proliferation (Fig. 1A). In addition, the effect of baicalin on non-tumorigenic normal breast epithelial cells was assessed by comparing the proliferation of MCF-7 and MCF-10 cells. Baicalin did not affect the proliferation of MCF-10 cells, indicating that this compound mediated growth arrest of breast cancer cell lines without affecting the nontumorigenic normal breast epithelial cells (Fig. 1A). To further elucidate the mechanism of action of baicalin in breast cancer development, after $48 \mathrm{~h}$ of treatment, cell cycle analysis was performed by flow cytometry. In MCF-7 cells, the cell phase distributions before and after treatment with 20 and $30 \mu \mathrm{M}$ baicalin were as follows: G0/1 phase, $49.53 \pm 0.62$ vs. $55.34 \pm 1.74$ and $63.52 \pm 3.64 \%$; S phase, $31.75 \pm 1.24$ vs. $25.73 \pm 2.79$ and $25.51 \pm 3.61 \%$; and $\mathrm{G} 2 / \mathrm{M}$ phase, $18.71 \pm 0.45$ vs. $17.93 \pm 1.87$ and $17.66 \pm 2.2$, respectively. In MDA-MB-231 cells, the cell phase distributions before and after treatment with 20 and $30 \mu \mathrm{M}$ baicalin were as follows: G0/1 phase, $42.96 \pm 2.01$ vs. $53.1 \pm 1.74$ and $64.96 \pm 3.33 \%$; S phase, $29.53 \pm 1.12$ vs. $24.17 \pm 2.71$ and $24 \pm 2.29 \%$; and $\mathrm{G} 2 / \mathrm{M}$ phase, $17.51 \pm 1.79$ vs. $18.17 \pm 1.74$ and $13.41 \pm 2.48 \%$, respectively (Fig. $1 \mathrm{~B}$ and C). These results indicate that the proportion of cells in the $S$ phase was significantly reduced following treatment with baicalin, whereas the proportion of cells in the G0/1 phase was significantly increased, suggesting that baicalin induces G1/S arrest. Compared with MCF-7 cells, baicalin did not affect the cell cycle distribution of MCF-10 cells (Fig. 1B and C).

Baicalin suppresses the invasion and migration of breast cancer cells. The Transwell assay was employed to evaluate the effect of baicalin on the invasion of MCF-7 and MDA-MB-231 cells. The cells were manually counted in 6 wells per group. The mean number of invasive cells, as determined by microscopy, 


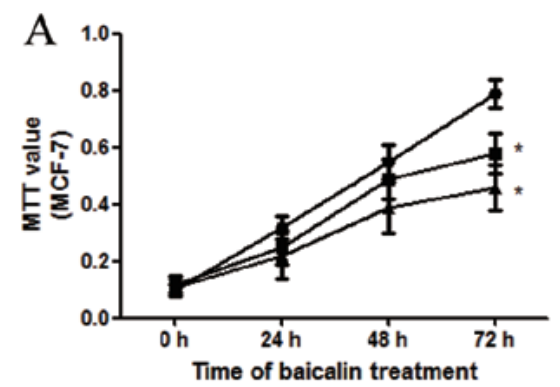

B
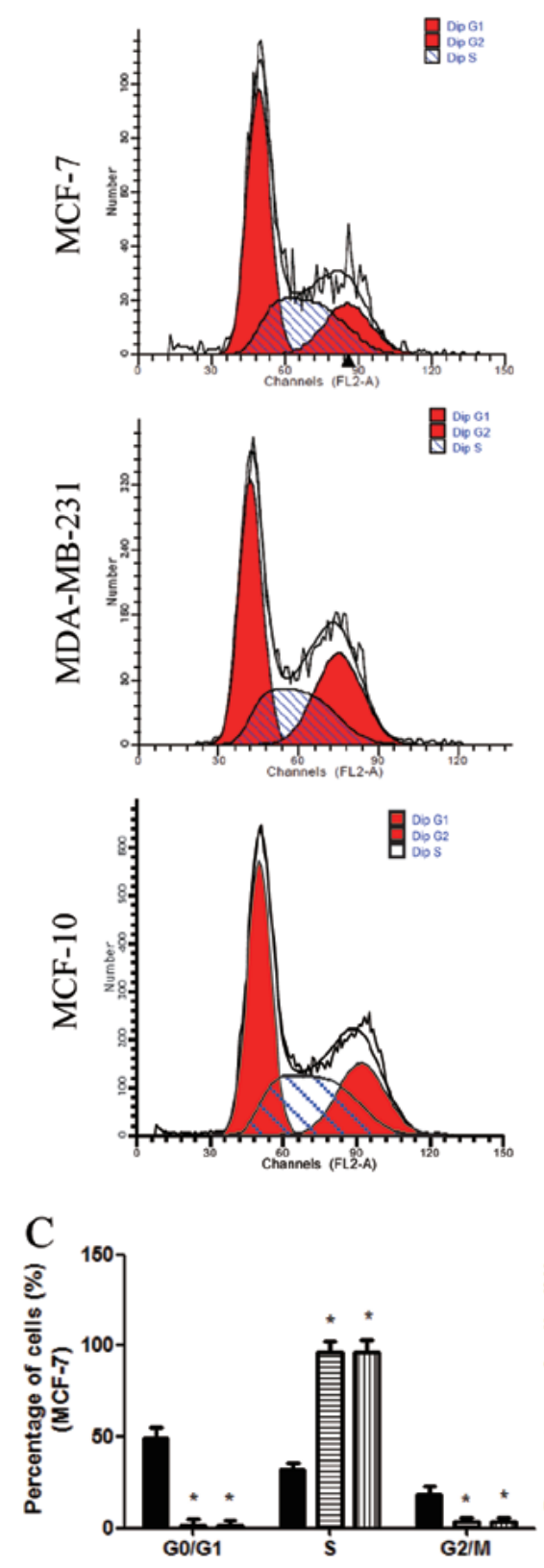

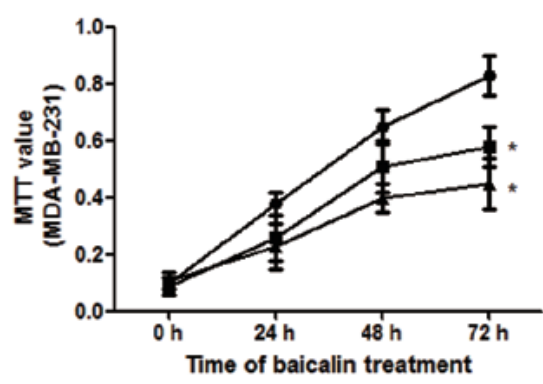

$20 \mu \mathrm{M}$
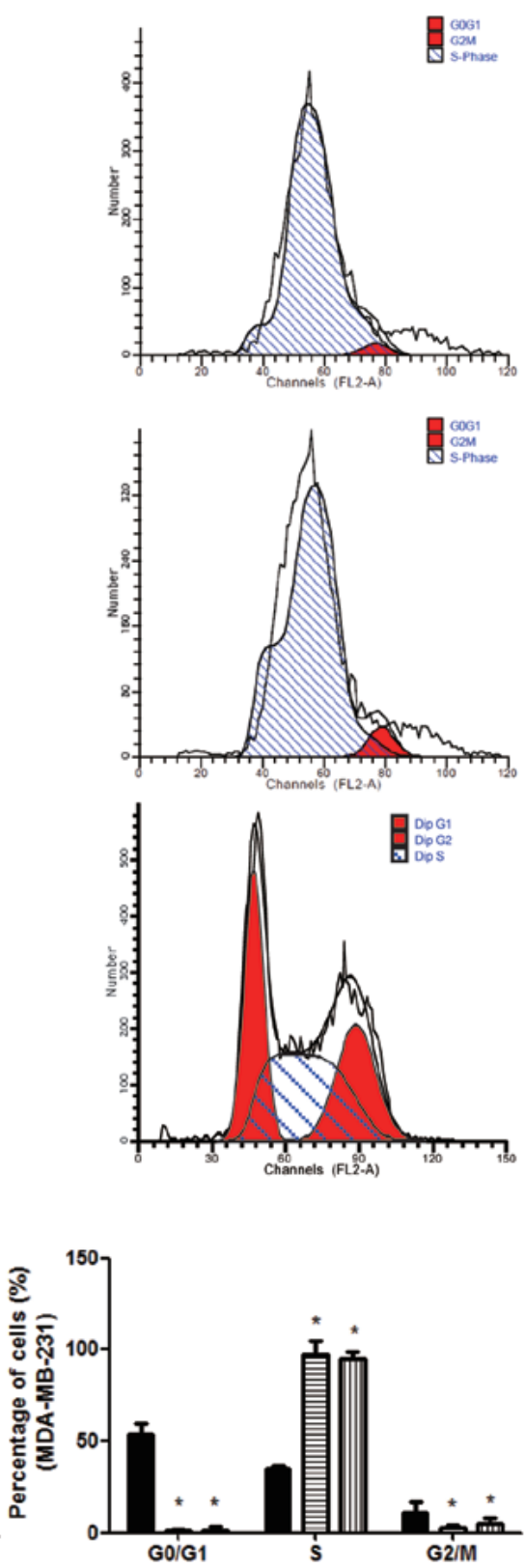

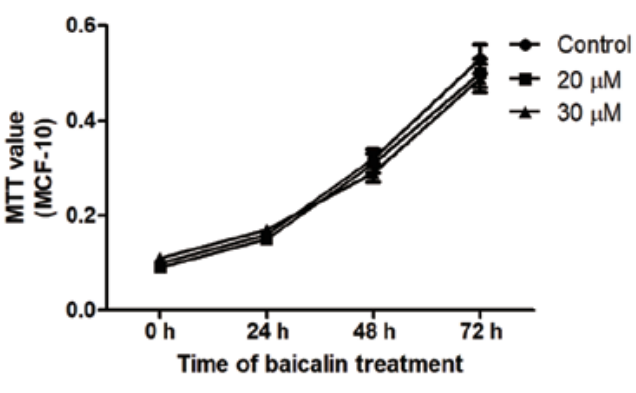

$30 \mu \mathrm{M}$
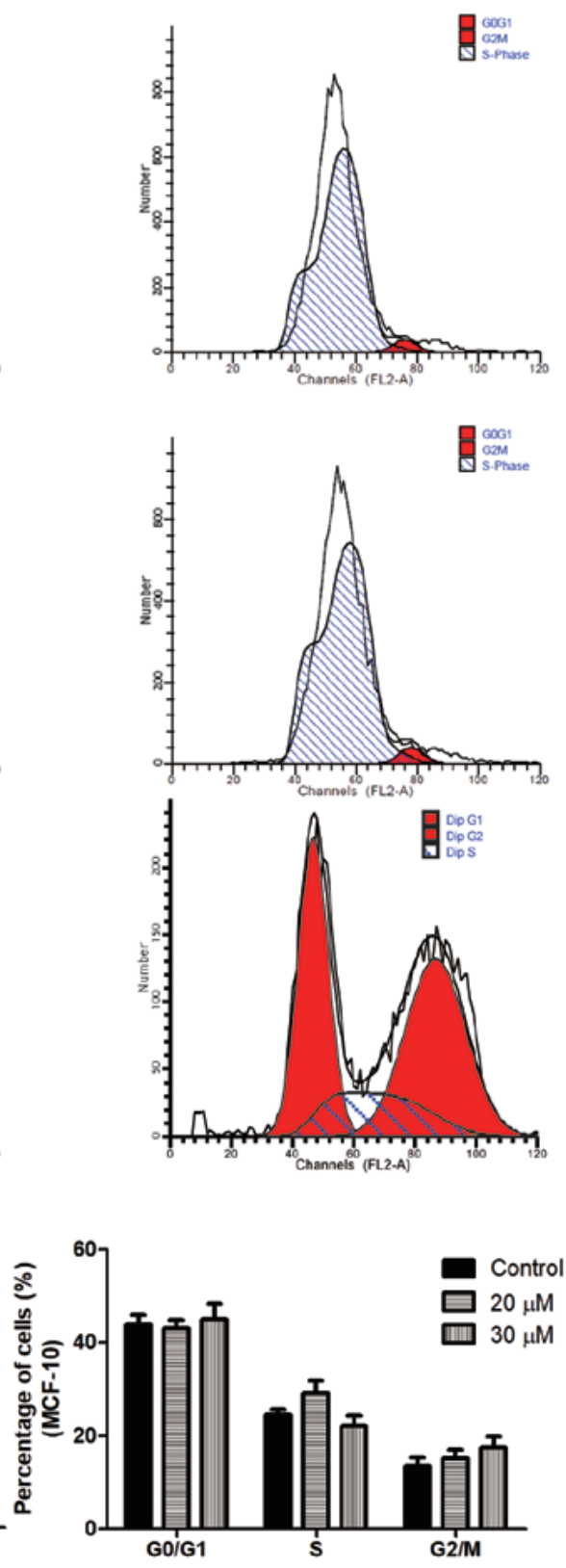

Figure 1. Baicalin suppresses breast cancer cell proliferation. (A) Growth curves represent the effect of baicalin on cell proliferation in MCF-7 and MDA-MB231 breast cancer cells and MCF-10 normal breast epithelial cells. (B) Flow cytometry results demonstrate the effect of baicalin on cell phase distribution in MCF-7 and MDA-MB-231 breast cancer cells and MCF-10 normal breast epithelial cells. (C) Quantitative results of flow cytometry. ${ }^{*} \mathrm{P}<0.05$ vs. the control group. The results are presented as mean \pm standard error $(n=6)$.

was $100 \pm 19.5,43 \pm 13.7$ and $41 \pm 13.3$ in untreated MCF-7 cells, and those treated with 20 and $30 \mu \mathrm{M}$ baicalin, respectively. The mean number of invading cells, as determined by microscopy, was $100 \pm 13.6,54 \pm 15.3$ and $44 \pm 16.3$ in untreated MBA-MB-231 cells, and those treated with 20 and $30 \mu \mathrm{M}$ baicalin, respectively. Therefore, the number of invading cells 
A
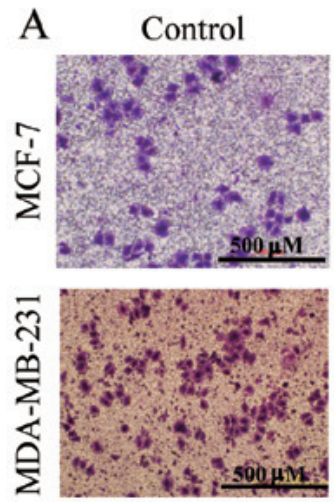

$20 \mu \mathrm{M}$
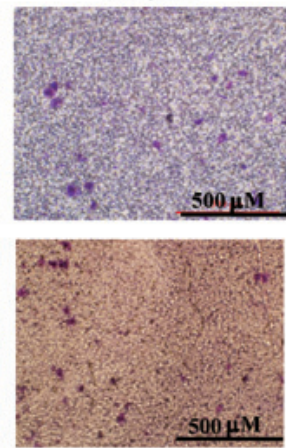

$30 \mu \mathrm{M}$
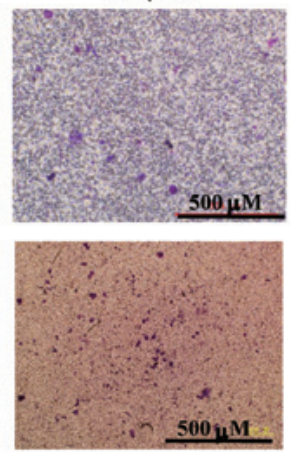

B

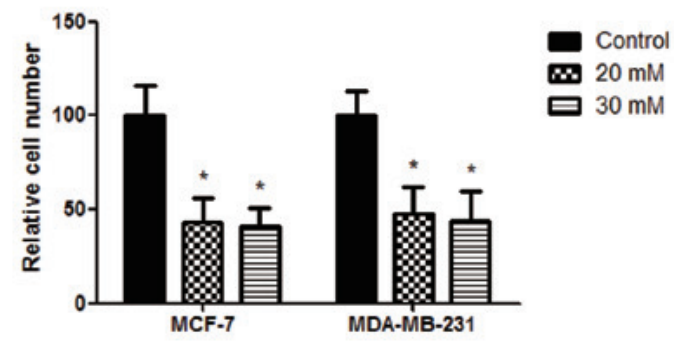

C MCF-7

MDA-MB-231
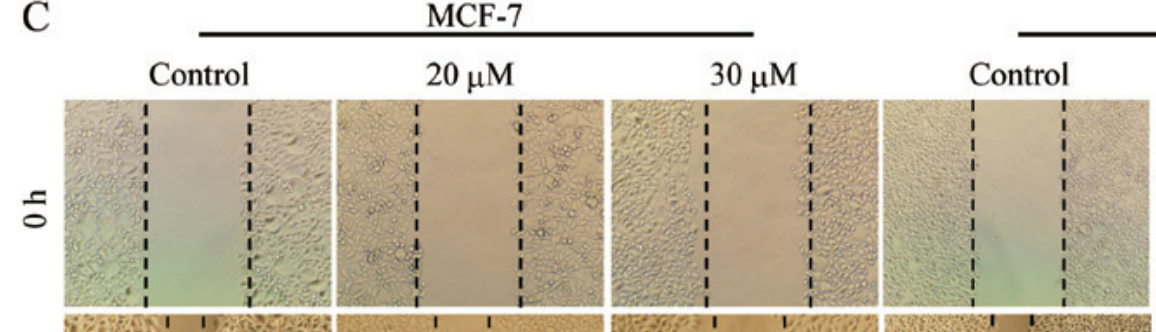

$20 \mu \mathrm{M}$

$30 \mu \mathrm{M}$
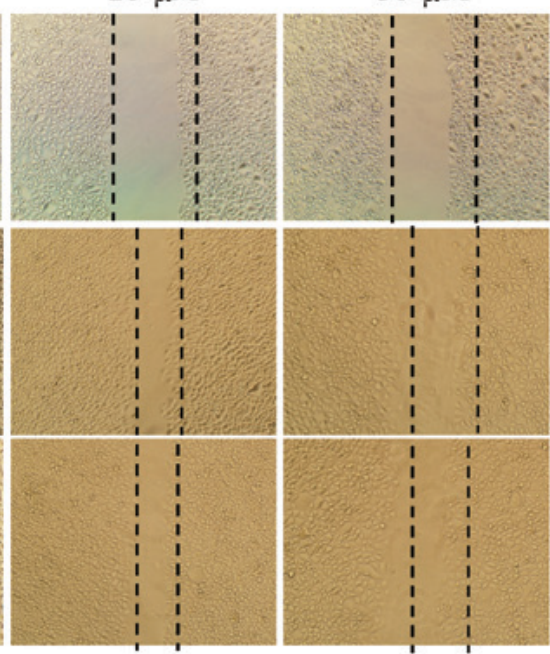

D
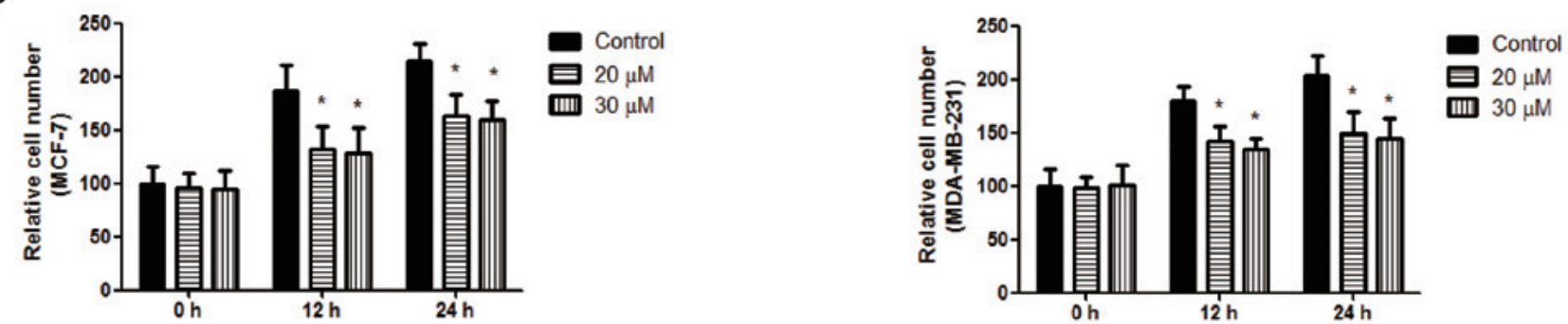

Figure 2. Baicalin suppresses breast cancer cell invasion and migration. (A) Transwell migration assays in baicalin-treated MCF-7 and MDA-MB-231 breast cancer cells and control cells. (B) Quantitative results of the invasion assays. (C) Scratch wound in baicalin-treated MCF-7 and MDA-MB-231 breast cancer cells and control cells. (D) Quantitative results of migration assays. " $\mathrm{P}<0.05$ vs. the control group. The results are presented as mean \pm standard error ( $\mathrm{n}=6$ ).

in the treatment groups was significantly reduced compared with that in the untreated control group (Fig. 2A and B).

Next, a wound healing assay was performed to explore the effects of baicalin on the migration of MCF-7 and MDA-MB-231 cells. The cells were manually counted in 6 wells per group. After $24 \mathrm{~h}$, the number of migrating MCF-7 cells was $115 \pm 16.3,67 \pm 7.7$ and $64 \pm 10.1$ in untreated cells, and those treated with and 20 and $30 \mu \mathrm{M}$ baicalin, respectively. The number of migrating MDA-MB cells was $103 \pm 12.6$, $52 \pm 10.6$ and $44 \pm 7.3$ in untreated cells, and those treated with 20 and $30 \mu \mathrm{M}$ baicalin, respectively. Therefore, the number of migrating cells in the treatment groups was significantly reduced compared with that in the untreated control group (Fig. 2C and D).
Baicalin suppresses breast cancer tumor growth in xenograft mice. To further explore the effects of baicalin on breast cancer growth, an MBA-MB-231 xenograft mouse model was employed, using 6 mice per group. After 25 days, the tumor volumes were smaller in the MBA-MB-231 cell xenograft mice treated with 100 and $200 \mathrm{mg} / \mathrm{kg}$ baicalin compared with the untreated group $\left(124.77 \pm 38.33\right.$ and $116.22 \pm 35.64$ vs. $363.63 \pm 47.63 \mathrm{~mm}^{3}$, respectively; Fig. 3A-C). In the control group, the longest diameter of the largest subcutaneous tumor was $15.62 \mathrm{~mm}$. The tumor weights were also reduced in the 100 and $200 \mathrm{mg} / \mathrm{kg}$ baicalin treatment groups compared with the untreated group $(0.12 \pm 0.03$ and $0.10 \pm 0.05$ vs. $0.25 \pm 0.02$ g, respectively; Fig. $3 B$ and D). No multiple subcutaneous tumors or peritonitis were observed in mice after being injected with MDA-MB-231 cells or baicalin. 
A

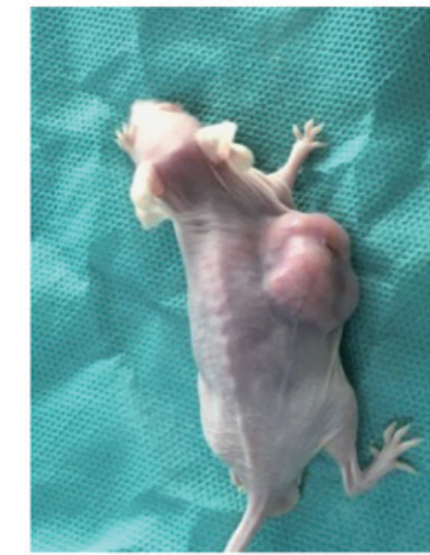

B

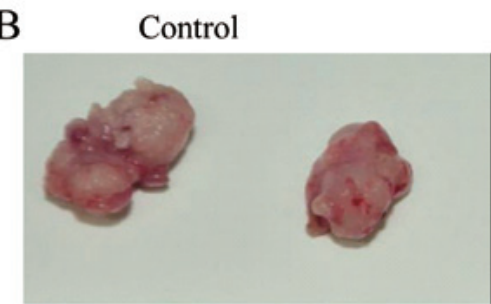

$\mathrm{C}$

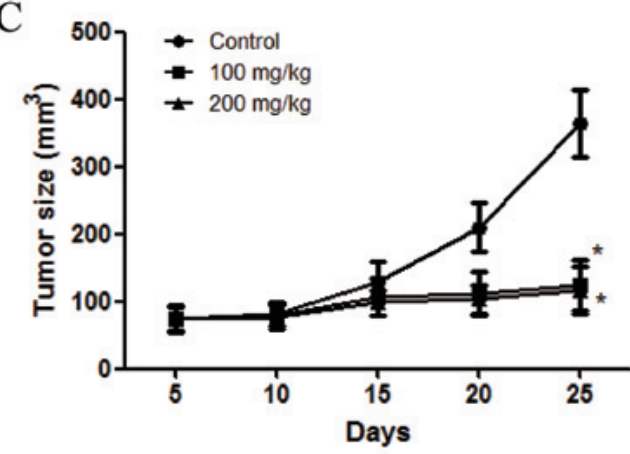

$100 \mathrm{mg} / \mathrm{kg}$

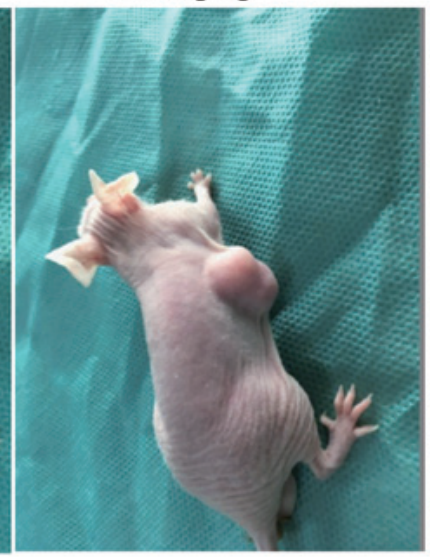

$100 \mathrm{mg} / \mathrm{kg}$
$200 \mathrm{mg} / \mathrm{kg}$

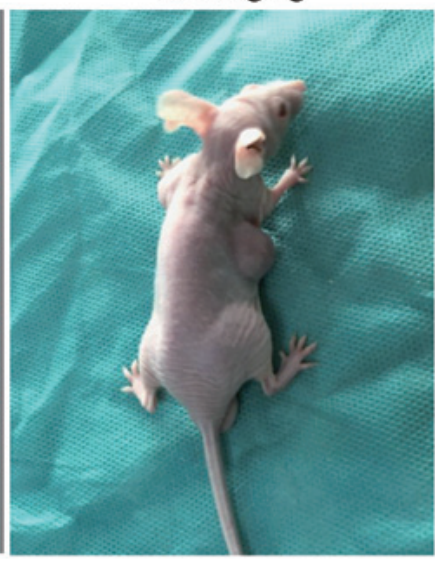

$200 \mathrm{mg} / \mathrm{kg}$

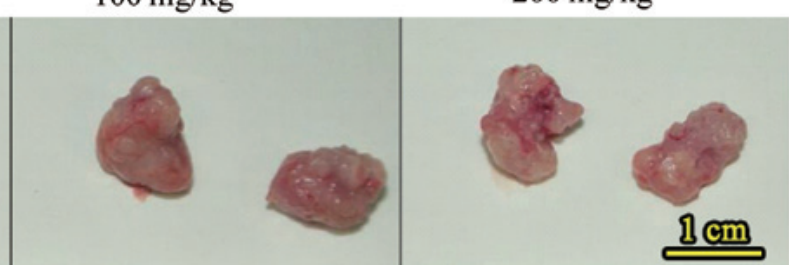

D

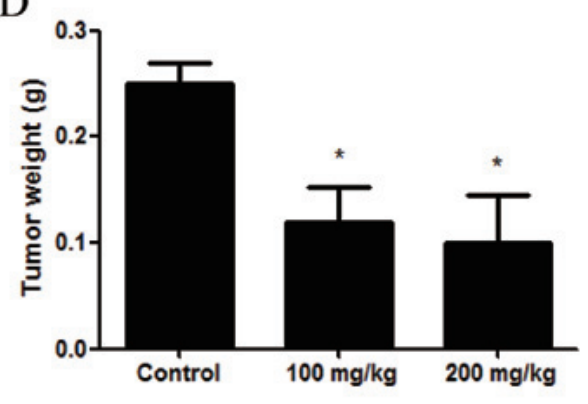

Figure 3. Baicalin suppresses tumor growth in xenograft mice. (A) Representative results of the effects of baicalin in xenograft tumors in nude mice. (B) Representative results of baicalin treatment in xenograft tumors. (C) Subcutaneous tumor growth curves for baicalin-treated and untreated xenograft mice in at different time points. (D) Tumor weight in nude mice was measured at 30 days. ${ }^{*} \mathrm{P}<0.05$ vs. the control group. The results are presented as mean \pm standard error ( $\mathrm{n}=6$ ).

Baicalin inhibits the secretion of TNF- $\alpha$ and IL-1 $\beta$ into cell media and mouse serum. To investigate whether baicalin modulates the inflammatory process by regulating the secretion of cytokines, the serum levels of TNF- $\alpha$ and IL-1 $\beta$ were measured in vitro and in vivo by ELISA. The cells were manually counted in 6 wells per group; the number of mice per group was $n=6$. As shown in Fig. 4A and B, high levels of the pro-inflammatory cytokines TNF- $\alpha$ and IL-1 $\beta$ were detected in the medium of MCF-7 and MBA-MB-231 cells in the control group. By contrast, the levels of these cytokines were significantly lower in the baicalin-treated groups (20 and $30 \mu \mathrm{M}$ ) compared with the untreated group. However, there was no significant difference in the cytokine levels between mice treated with 20 and those treated with $30 \mu \mathrm{M}$ baicalin. Similar results were observed in serum samples obtained from mice on day30 following treatment with 100 or $200 \mathrm{mg} / \mathrm{kg}$ baicalin (Fig. 4C).

Baicalin suppresses the activation of $N F-k B$. Based on the key role of NF- $\kappa B$ in the regulation of tumor-associated inflammation and cancer progression, we next investigated the association between baicalin and NF- $\mathrm{kB}$. The cells were manually counted in 6 wells per group, and the number of mice per group was $n=6$. In a dual luciferase reporter assay, a 3-fold lower luminescence intensity was observed in cells treated with 20 and $30 \mu \mathrm{M}$ baicalin compared with the control group in vitro, indicating that the activation of NF- $\mathrm{KB}$ was inhibited by baicalin (Fig. 5A). Western blot analysis further confirmed that NF- $\mathrm{\kappa B}$ was inhibited by baicalin in breast cancer cells in vivo and in vitro. The phosphorylation levels of IкB kinase $\beta$ (IKK $\beta$ ) and NF-кB-p65 were reduced, whereas the expression of $\mathrm{I} \mathrm{B} \alpha$, an essential NF- $\kappa \mathrm{B}$ inhibitor, was markedly upregulated in response to baicalin treatment (Fig. 5B and C).

NF- $\mathrm{kB}$ also regulates oncological behavior. The expression of cyclin D1 (CCNDI), BCL2, BIRC2 (cIAP1) and BIRC3 (cIAP2) were examined by RT-qPCR. The results demonstrated that baicalin reduced the expression of these genes, indicating that baicalin may suppress cell proliferation by inhibiting NF-kB-induced expression of $C C N D 1$, and suppress cell invasion and migration by inhibiting NF-kB-induced expression of BCL2, BIRC2 and BIRC3 (Fig. 5D). 
A
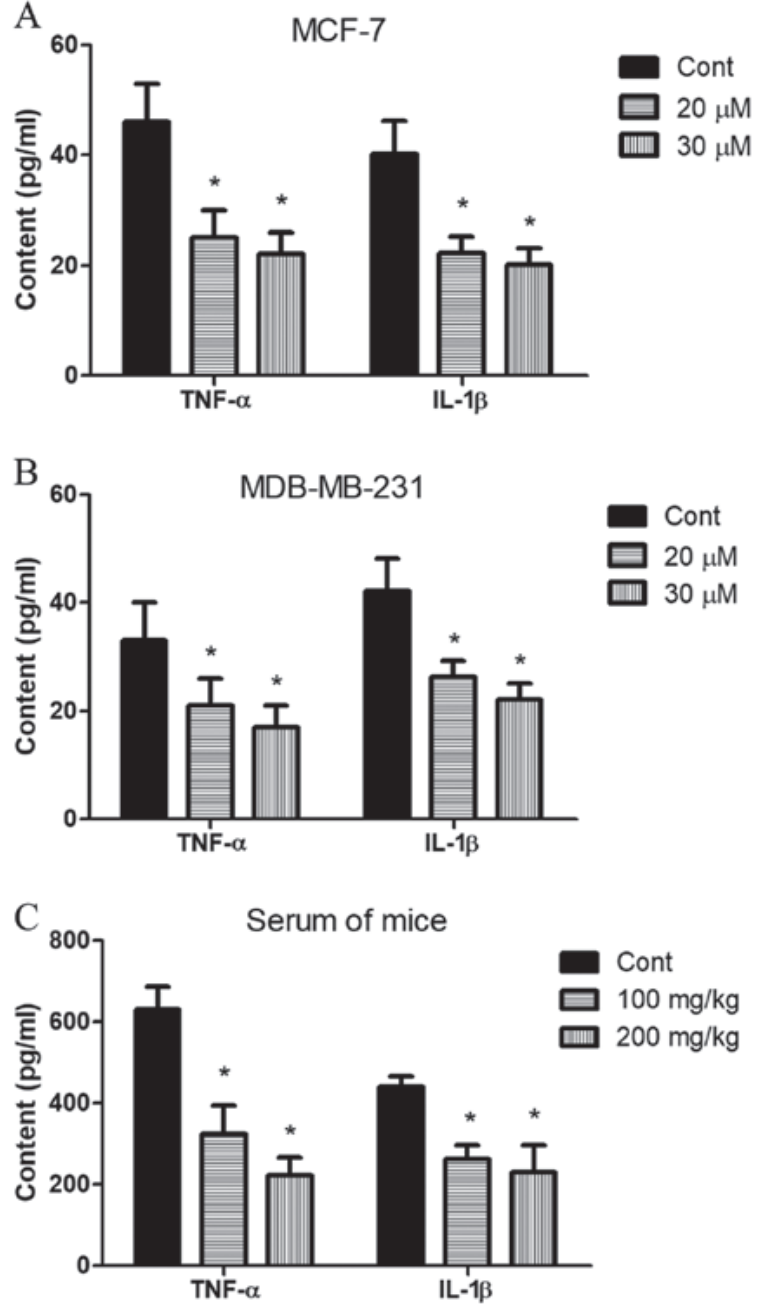

Figure 4. Baicalin suppresses the production of TNF- $\alpha$ and IL-1 $\beta$ in vivo and in vitro. (A) The levels of TNF- $\alpha$ and IL-1 $\beta$ were measured in the medium of baicalin-treated and untreated MCF-7 cells. (B) The levels of TNF- $\alpha$ and IL-1 $\beta$ were measured in the medium of baicalin-treated and untreated MDA-MB-231 cells. (C) The levels of TNF- $\alpha$ and IL-1 $\beta$ were measured in the serum of baicalin-treated and untreated xenograft mice at day 30 ${ }^{*} \mathrm{P}<0.05$ vs. the control group. The results are presented as mean \pm standard error $(n=6)$. TNF, tumor necrosis factor; IL, interleukin.

\section{Discussion}

Breast cancer is one of the most commonly diagnosed types of malignancy among women worldwide $(1,2)$. The current standard therapies for breast cancer are associated with numerous side effects. Traditional Chinese herbal medicines have been suggested as potential new therapeutic drugs with a more tolerable toxicity profile $(3,4)$. NF- $\kappa \mathrm{B}$ has been demonstrated to be a key factor enabling precancerous and malignant cells to escape apoptosis (5-7). Inhibition of $\mathrm{NF}-\kappa \mathrm{B}$ activity results in the partial release of cells from the G2/M arrest after curcumin treatment of MCF-7 cells $(8,9)$. Baicalin is a chemical commonly used to treat diseases of the CNS, hepatic disorders and inflammatory conditions $(10,11)$, and it inhibits lipopolysaccharide-induced inflammation caused by endotoxic shock $(12,16)$. Baicalin also inhibits ROS production in arteriosclerotic vascular disease by reducing the activation of the $N F-\kappa B$ signaling pathway (17). Given its ability to inhibit the activation of the $N F-\kappa B$ signaling pathway, it was hypothesized that baicalin, a traditional Chinese herbal medicine with few known side effects $(18,19)$, may suppress breast cancer growth. In the present study, the therapeutic efficacy of baicalin in regulating the inflammatory reaction in breast cancer was determined.

It was herein demonstrated that 20 and $30 \mu \mathrm{M}$ baicalin suppressed the invasion and migration of MCF-7 and MDA-MB-231 breast cancer cells (Fig. 2A-D). Furthermore, the results indicated that the mechanism through which baicalin suppresses breast cancer cell proliferation involves induction of $\mathrm{G} 1 / \mathrm{S}$ arrest (Fig. 1A-C). The results of in vivo experiments demonstrated that 100 and $200 \mathrm{mg} / \mathrm{kg}$ baicalin suppressed breast tumor growth in xenograft mice (Fig. 3A-D). Furthermore, baicalin mediated growth arrest of breast cancer cell lines without affecting non-tumorigenic normal breast epithelial cells (Fig. 1A-C). Treatment doses $<20 \mu \mathrm{M}$ did not induce significant effects in vitro, whereas treatment doses $<100 \mathrm{mg} / \mathrm{kg}$ also did not exert significant effects in vivo (data not shown). Taken together, these results indicate that baicalin is therapeutically effective in breast cancer.

The development of breast cancer has been strongly associated with inflammation (20). The conventional inflammatory reaction is mediated by numerous cytokines, including TNF- $\alpha$, IL-1 $\beta$, IL-6, TGF- $\beta$, IL-8 and IL-10, among others $(20,21)$. In the present study, it was demonstrated that baicalin significantly decreased the secretion of TNF- $\alpha$ and IL-1 $\beta$ into breast cancer cell medium in vitro (Fig. $4 \mathrm{~A}$ and B). Furthermore, baicalin significantly reduced the levels of TNF- $\alpha$ and IL-1 $\beta$ in the plasma of xenograft mice (Fig. 4C). Collectively, these data suggest that baicalin suppresses the inflammatory response by reducing the secretion of key inflammatory cytokines by MCF-7 and MDA-MB-231 breast cancer cells in vitro, with similar effects in xenograft mice.

TNF- $\alpha$ and IL-1 $\beta$ are key pro-inflammatory cytokines that exert their effects by regulating the NF-kB pathway through interaction with specific receptors on cell membranes $(22,23)$. The NF-kB pathway is a key mediator of inflammatory response in cancer (24). Several studies on acute and chronic inflammation have demonstrated that the anti-inflammatory activity of baicalin is associated with the regulation of NF- $\mathrm{kB}$. For example, in Staphylococcus aureus-induced mastitis and cigarette smoke-induced inflammation, baicalin effectively attenuated inflammation through inhibition of NF- $\mathrm{KB}$ activation $(25,26)$. In addition, NF-kB activation plays a pathogenic role in cell proliferation and has an anti-apoptotic effect in breast cancer (5-7). A recent study also demonstrated that treatment with the NF- $\kappa \mathrm{B}$ inhibitor, BAY117082, suppressed breast cancer tumor growth in xenograft mice (24). Consistent with these reports, we herein observed that baicalin suppressed the activation of NF-kB in vitro (Fig. 5A). Furthermore, the phosphorylation levels of NF-kB-p65 were reduced by baicalin treatment in a dose-dependent manner, not only in MCF-7 and MDA-MB-231 breast cancer cells, but also in xenograft mice (Fig. 5B and C). Taken together, these data suggest that the NF-kB pathway mediates the effect of baicalin inhibition of breast cancer progression.

To the best of our knowledge, no previous studies have investigated the regulatory mechanism baicalin on NF-kB to date. In the present study, the effects of baicalin on $N F-k B$ were found to involve $\mathrm{IkB}$. In its inactive form, $N F-k B$ is 
A

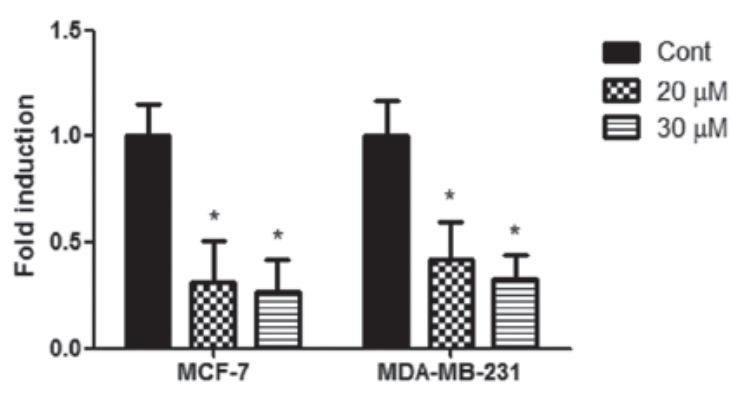

$\mathrm{C}$
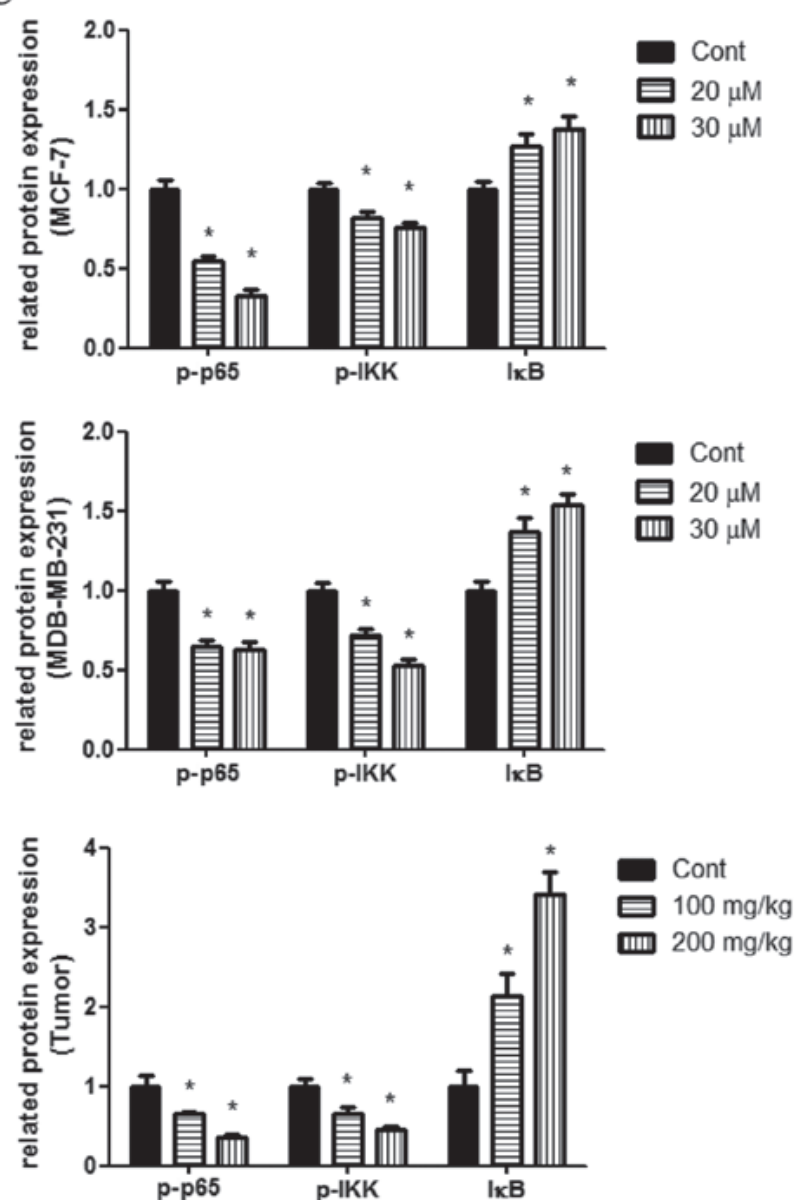

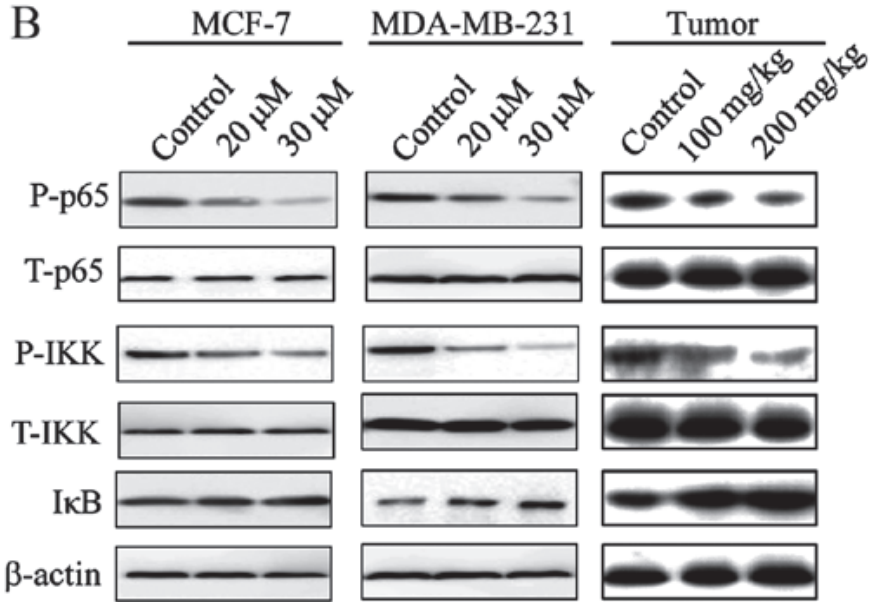

$\mathrm{D}$
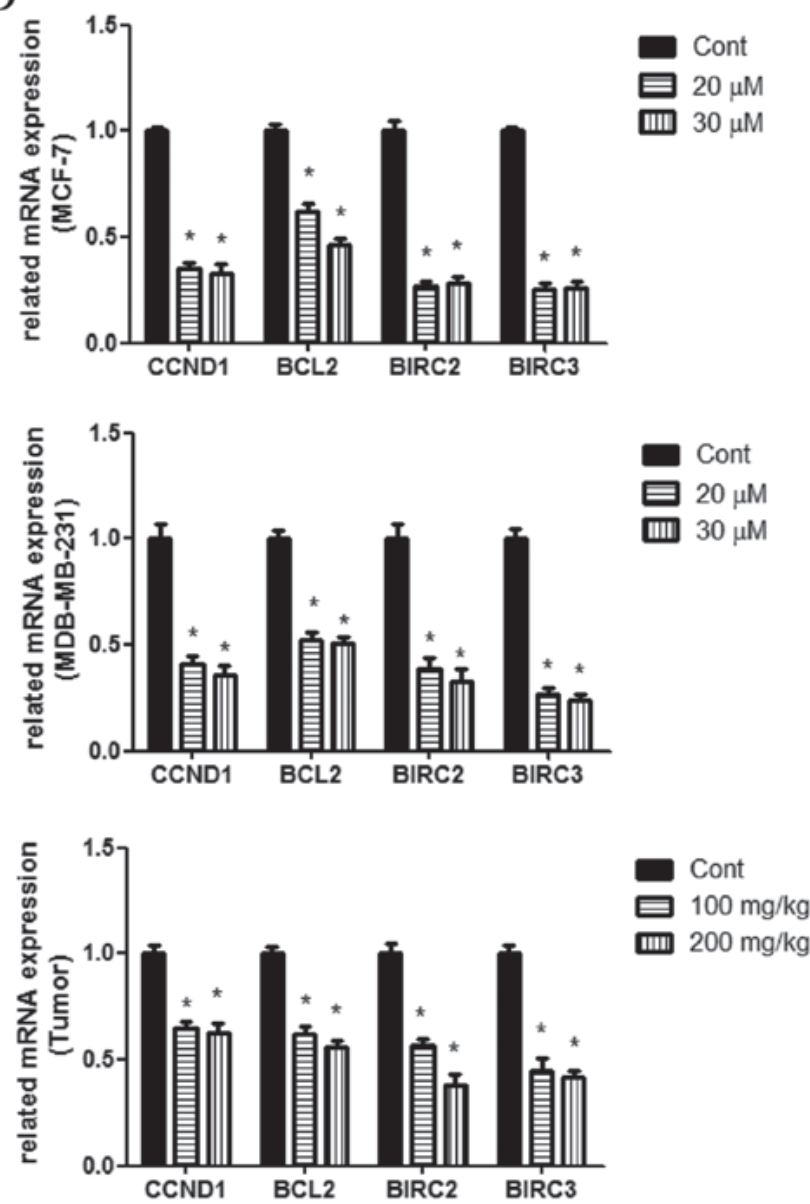

Figure 5. Baicalin suppresses the activation of NF-kB in vivo and in vitro. (A) NF-kB activation of baicalin-treated and untreated MCF-7 and MDA-MB-231 cells measured by dual luciferase reporter assay. (B) Phosphorylation of NF-kB-p65 and IKK $\alpha / \beta$, the expression of IkB $\alpha$, NF-kB-p65, IKK $\beta$ and $\beta$-actin in baicalin-treated and untreated MCF-7 and MDA-MB-231 cells and tumors of baicalin-treated and untreated xenograft mice. (C) Phosphorylation of NF-kB-p65/total NF-kB-p65, phosphorylation of IKK $\alpha / \beta /$ total IKK $\beta$, and IKB $\alpha / \beta$-actin ratios of baicalin-treated and untreated MCF-7 and MDA-MB-231 breast cancer cells and tumors in xenograft mice at day 30. (D) Gene expression of CCND1, BCL2, BIRC2 and BIRC3 of baicalin-treated and untreated MCF-7 and MDA-MB-231 breast cancer cells and tumors in xenograft mice at day $30 .{ }^{*} \mathrm{P}<0.05$ vs. the control group. The results are presented as mean \pm standard error (n=6). NF-kB, nuclear factor-kB; CCND1, cyclin D1.

sequestered in the cytoplasm and bound by members of the IkB family of inhibitor proteins. In tumors, the various stimuli that activate NF-kB cause phosphorylation of IkB, which is followed by its ubiquitination and subsequent degradation $(24,26)$. IkB proteins are phosphorylated by the IkB kinase complex (IKK). TNF- $\alpha$ and IL- $1 \beta$ can activate IKK and, thus, regulate the NF-kB pathway $(24,27)$. IKK-knockout mice have a dysfunctional NF-kB pathway, leading to embryonic fatality (28). The present study demonstrated that the levels of phosphorylated IKK $\beta$ were lower in the baicalin group, suggesting that baicalin suppresses the activity of IKK $\beta$ in breast cancer cells and xenograft mice (Fig. 5A-C). 
In addition, activated IKK phosphorylates IkB $\alpha$ (Ser32 and 36), and $\mathrm{IKB}_{\alpha}$ is ubiquitinated by Lys 21 and Lys22, the ubiquitinated IKB $\alpha$ is degraded and, thus, activated NF-kB is released (29). In the present study, the protein expression level of $\mathrm{IkB} \alpha$ was higher in the baicalin treatment groups, suggesting that, through suppressing the activity of IKK $\beta$, baicalin inhibited the degradation of $\operatorname{IkB} \alpha$, thus inhibiting the activation of NF-kB in breast cancer cells and xenograft mice. However, further investigation is required to elucidate the underlying molecular mechanisms.

$C C N D 1$ is involved in regulation of the cell cycle, and NF-kB promotes the expression of CCNDI and, thus, cell proliferation $(30,31)$. Therefore, baicalin treatment leads to a reduction of $C C N D 1$ expression, which indicates that baicalin likely inhibits cell proliferation via downregulation of NF-kB-induced expression of $C C N D 1$. Inflammationactivated NF-kB also induces expression of $B C L 2, B I R C 2$ and $B I R C 3$, the proteins encoded by which inhibit the activation of various apoptosis-related enzymes, thereby reducing the apoptosis of tumor cells $(31,32)$. The BCL2 family of proteins has anti-apoptotic members that are expressed in several types of cancer, including lymphoma, lung, prostate and breast cancer (33). BIRC2 and BIRC3 are members of the inhibitor of apoptosis protein family, which are expressed in several types of cancer, and are associated with chemoresistance, disease progression and poor prognosis (34). The present study demonstrated that baicalin significantly inhibited the expression of these apoptosis-inhibiting genes (Fig. 5D). NF-kB is crucial for cell invasion and migration in breast cancer (35). Therefore, it may be inferred that the ability of baicalin to inhibit invasion and migration of MCF-7 and MDA-MB-231 breast cancer cells is likely to be associated with inhibition of the activation of NF-kB. However, the detailed mechanism of $\mathrm{NF}-\mathrm{KB}$-induced cell invasion and migration remains unclear. Therefore, the detailed mechanism underlying baicalininduced inhibition of cell invasion and migration requires further research.

In summary, the results of the present study clearly demonstrated that baicalin, an important component isolated from the dry root of $S$. baicalensis Georgi, has therapeutic properties against breast cancer via inhibition of the inflammatory response, through the suppression of inflammatory cytokine-activated NF-kB-p65, and the expression of CCND1, $B C L 2, B I R C 2$ and BIRC3. This process inhibits breast cancer cell proliferation, invasion and migration, and downregulates the expression of anti-apoptotic factors in vitro and in vivo. Furthermore, baicalin did not affect the non-tumorigenic normal breast epithelial cells.

\section{Acknowledgements}

Not applicable.

\section{Funding}

The present study was supported by grants from the National Natural Science Foundation of China (no. 31771601), the Natural Science Foundation of Heilongjiang Province (no. QC2014C016), the Innovation and Technology Special Fund for Researchers of Harbin City (no. 2013RFXXJ010), and the China Postdoctoral Science Foundation Special Financial Grant (no. 2013T60353).

\section{Ethics approval}

The present study was approved by the Ethics Committee for Animal Experimentation of the School of Life Science and Technology, Harbin Institute of Technology. All animal experiments were performed according to the Guidelines for the Care and Use of Experimental Animals and approved by the Heilongjiang Province People's Congress (http://www. nicpbp.org.cn/sydw/CL0249/2730.html).

\section{Patient consent for publication}

Not applicable.

\section{Availability of data and materials}

The datasets generated and analyzed in the present study are all included in this published article.

\section{Authors' contributions}

QW conceived the idea. YG, HL and HZW designed the experiments. YG, HLH and $\mathrm{HJH}$ performed the in vitro experiments. HZW, HJS and CJJ performed the in vivo experiments. $\mathrm{XH}$, DL and SC contributed to gene expression analysis. NG and QG contributed to protein expression analysis. HL performed statistical analysis. HJH and NG made figures. YG and HLH wrote the manuscript. All authors have read and approved the final manuscript.

\section{Competing interests}

The authors declare that they have no competing interests.

\section{References}

1. Guo L, Liu S, Zhang S, Chen Q, Zhang M, Quan P, Lu J and Sun X: C-reactive protein and risk of breast cancer: A systematic review and meta-analysis. Sci Rep 5: 10508, 2015.

2. Zhang HY, Liang F, Wang F, Zhang JW, Wang L, Kang XG, Wang $J$ and Duan QL: In vitro effects of HAS-2 gene silencing on the proliferation and apoptosis of the MCF-7 human breast cancer cell line. Cell Physiol Biochem 40: 807-817, 2016.

3. Vulcano E, Montesano M, Battista C, Carino R, Perrone G, Vincenzi B and Altomare V: Urinary complications from breast cancer metastasis: Case report and review of the literature. G Chir 31: 243-245, 2010.

4. Al-Sadoon MK, Abdel-Maksoud MA, Rabah DM and Badr G: Induction of apoptosis and growth arrest in human breast carcinoma cells by a snake (Walterinnesia aegyptia) venom combined with silica nanoparticles: Crosstalk between $\mathrm{Bcl} 2$ and caspase-3. Cell Physiol Biochem 30: 653-665, 2012.

5. Naugler WE and Karin M: NF-kappaB and cancer-identifying targets and mechanisms. Curr Opin Genet Dev 18: 19-26, 2008.

6. Biswas DK, Martin KJ, McAlister C, Cruz AP, Graner E, Dai SC and Pardee AB: Apoptosis caused by chemotherapeutic inhibition of nuclear factor-kappaB activation. Cancer Res 63: 290-295, 2003

7. Karin M: Nuclear factor-kappaB in cancer development and progression. Nature 441: 431-436, 2006.

8. Gutierrez CM, Lopez-Valdez R, Subramani R, Arumugam A Nandy S, Rajamanickam V, Ravichandran V and Lakshmanaswamy R: A breast tissue protein expression profile contributing to early parity-induced protection against breast cancer. Cell Physiol Biochem 37: 1671-1685, 2015. 
9. Berrak Ö, Akkoç Y, Arısan ED, Çoker-Gürkan A, ObakanYerlikaya P and Palavan-Ünsal N: The inhibition of PI3K and $\mathrm{NF}_{\kappa} \mathrm{B}$ promoted curcumin-induced cell cycle arrest at $\mathrm{G} 2 / \mathrm{M}$ via altering polyamine metabolism in $\mathrm{Bcl}-2$ overexpressing MCF-7 breast cancer cells. Biomed Pharmacother 77: 150-160, 2016.

10. Xu XF, Cai BL, Guan SM, Li Y, Wu JZ, Wang Y and Liu B: Baicalin induces human mucoepidermoid carcinoma Mc3 cells apoptosis in vitro and in vivo. Invest New Drugs 29: 637-645, 2011.

11. Hou J, Wang J, Zhang P, Li D, Zhang C, Zhao H, Fu J, Wang B and Liu J: Baicalin attenuates proinflammatory cytokine production in oxygen-glucose deprived challenged rat microglial cells by inhibiting TLR4 signaling pathway. Int Immunopharmacol 14: 749-757, 2012.

12. Liu LL, Gong LK, Wang H, Xiao Y, Wu XF, Zhang YH, Xue X, Qi XM and Ren J: Baicalin inhibits macrophage activation by lipopolysaccharide and protects mice from endotoxin shock. Biochem Pharmacol 75: 914-922, 2008.

13. Yin F, Liu J, Ji X, Wang Y, Zidichouski J and Zhang J: Baicalin prevents the production of hydrogen peroxide and oxidative stress induced by $\mathrm{A} \beta$ aggregation in SH-SY5Y cells. Neurosci Lett 492: 76-79, 2011.

14. Taira Z, Yabe K, Hamaguchi Y, Hirayama K, Kishimoto M, Ishida S and Ueda Y: Effects of Sho-saiko-to extract and its components, Baicalin, baicalein, glycyrrhizin and glycyrrhetic acid, on pharmacokinetic behavior of salicylamide in carbon tetrachloride intoxicated rats. Food Chem Toxicol 42: 803-807, 2004.

15. Xu Y, Feng Y, Li H and Gao Z: Ferric citrate CYP2E1independently promotes alcohol-induced apoptosis in HepG2 cells via oxidative/nitrative stress which is attenuated by pretreatment with baicalin. Food Chem Toxicol 50: 3264-3272, 2012.

16. Cao Y, Mao X, Sun C, Zheng P, Gao J, Wang X, Min D, Sun H, $\mathrm{Xie} \mathrm{N}$ and Cai J: Baicalin attenuates global cerebral ischemia/ reperfusion injury in gerbils via anti-oxidative and anti-apoptotic pathways. Brain Res Bull 85: 396-402, 2011.

17. Dinda B, Dinda S, Das Sharma S, Banik R, Chakraborty A and Dinda M: Therapeutic potentials of baicalin and its aglycone, baicalein against inflammatory disorders. Eur J Med Chem 131: 68-80, 2017.

18. Wang HZ, Wang HH, Huang SS, Zhao H, Cao YG, Wang GZ, Wang D, Wang ZG and Liu YH: Inhibitory effect of baicalin on collagen-induced arthritis in rats through the nuclear factor- $\kappa \mathrm{B}$ pathway. J Pharmacol Exp Ther 350: 435-443, 2014

19. Yang X, Yang J and Zou H: Baicalin inhibits IL-17-mediated joint inflammation in murine adjuvant-induced arthritis. Clin Dev Immunol 2013: 268065, 2013.

20. Barham W, Chen L, Tikhomirov O, Onishko H, Gleaves L, Stricker TP, Blackwell TS and Yull FE: Aberrant activation of $\mathrm{NF}-\kappa \mathrm{B}$ signaling in mammary epithelium leads to abnormal growth and ductal carcinoma in situ. BMC Cancer 15: 647, 2015

21. Kim HJ, Hawke N and Baldwin AS: NF-kappaB and IKK as therapeutic targets in cancer. Cell Death Differ 13: 738-747, 2006.

22. Bai HY, Mogi M, Nakaoka H, Kan-No H, Tsukuda K, Wang XL, Shan BS, Kukida M, Yamauchi T, Higaki A, et al: Synergistic inhibitory effect of rosuvastatin and angiotensin II type 2 receptor agonist on vascular remodeling. J Pharmacol Exp Ther 358: 352-358, 2016.
23. Gibson CJ, Hossain MM, Richardson JR and Aleksunes LM: Inflammatory regulation of ATP binding cassette efflux transporter expression and function in microglia. J Pharmacol Exp Ther 343: 650-660, 2012.

24. Goswami S and Sharma-Walia N: Osteoprotegerin rich tumor microenvironment: Implications in breast cancer. Oncotarget 7: 42777-42791, 2016.

25. Lixuan Z, Jingcheng D, Wenqin Y, Jianhua H, Baojun L and Xiaotao F: Baicalin attenuates inflammation by inhibiting NF-kappaB activation in cigarette smoke induced inflammatory models. Pulm Pharmacol Ther 23: 411-419, 2010.

26. Guo M, Zhang N, Li D, Liang D, Liu Z, Li F, Fu Y, Cao Y, Deng X and Yang Z: Baicalin plays an anti-inflammatory role through reducing nuclear factor- $\mathrm{\kappa B}$ and $\mathrm{p} 38$ phosphorylation in S. aureusinduced mastitis. Int Immunopharmacol 16: 125-130, 2013.

27. Delhase M, Hayakawa M, Chen Y and Karin M: Positive and negative regulation of IkappaB kinase activity through IKKbeta subunit phosphorylation. Science 284: 309-313, 1999.

28. Shi C, Zhang N, Feng Y, Cao J, Chen X and Liu B: Aspirin inhibits IKK- $\beta$-mediated prostate cancer cell invasion by targeting matrix metalloproteinase-9 and urokinase-type plasminogen activator. Cell Physiol Biochem 41: 1313-1324, 2017.

29. Ingrassia R, Lanzillotta A, Sarnico I, Benarese M, Blasi F, Borgese L, Bilo F, Depero L, Chiarugi A, Spano PF, et al: 1B/ (-)IRE DMT1 expression during brain ischemia contributes to

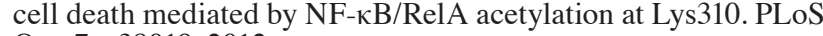
One 7: e38019, 2012

30. Lee-Rivera I, López E, Parrales A, Alvarez-Arce A and LópezColomé AM: Thrombin promotes the expression of Ccnd1 gene in RPE cells through the activation of converging signaling pathways. Exp Eye Res 139: 81-89, 2015.

31. Wang J, Wang Q, Cui Y, Liu ZY, Zhao W, Wang CL, Dong Y, Hou L, Hu G, Luo C, et al: Knockdown of cyclin D1 inhibits proliferation, induces apoptosis, and attenuates the invasive capacity of human glioblastoma cells. J Neurooncol 106: 473-484, 2012.

32. Jin H, Dong YY, Zhang H, Cui Y, Xie K and Lou G: shRNA depletion of cIAP1 sensitizes human ovarian cancer cells to anticancer agent-induced apoptosis. Oncol Res 22: 167-176, 2014.

33. Badr G, Al-Sadoon MK and Rabah DM: Therapeutic efficacy and molecular mechanisms of snake (Walterinnesia aegyptia) venom-loaded silica nanoparticles in the treatment of breast cancer- and prostate cancer-bearing experimental mouse models. Free Radic Biol Med 65: 175-189, 2013.

34. Gyrd-Hansen M, Meier P and Ps IA: IAPs: From caspase inhibitors to modulators of NF-kappaB, inflammation and cancer. Nat Rev Cancer 10: 561-574, 2010.

35. Huber MA, Azoitei N, Baumann B, Grünert S, Sommer A, Pehamberger H, Kraut N, Beug $\mathrm{H}$ and Wirth T: NF-kappaB is essential for epithelial-mesenchymal transition and metastasis in a model of breast cancer progression. J Clin Invest 114: 569-581, 2004. 